\title{
STUDI PEMAKAIAN DAYA "SOLAR CELL-HYBRID OFF GRID" GEDUNG LABORATORIUM ENERGI SURYA-JURUSAN TEKNIK KONVERSI ENERGI-POLBAN
}

\author{
Ign. Riyadi. Mardiyanto dan Alvera Apridalianti Melkias \\ Jurusan Teknik Konversi Energi - Politeknik Negeri Bandung \\ email : Ig_R_M@yahoo.com
}

\begin{abstract}
Solar energy is a renewable source that has never been exhausted; this energy will not reveal pollution into environment such as another power plant. Solar Power Plant is one of renewable source that become an alternative source in the future. One of application of this system is Hybrid Solar Power Plant, this power plant it is use to accomplish electricity energy consumption in Solar Laboratory Energy Conversion Engineering POLBAN with benefitted solar energy as electricity energy source. Electricity of energy there is resulted dependent on high and low solar light intensity. This paper is analyzed for both of supply and demand electricity in Laboratory of Solar Energy - Energy Conservation Engineering Department-POLBAN.
\end{abstract}

Keyword: renewable source, Hybrid Solar Power Plant

\section{PENDAHULUAN}

Pada era global, manusia tidak terlepas dengan keberadaan energi listrik. Hampir semua aktivitas yang dilakukan menggunakan energi listrik, bahkan energi listrik menjadi penunjang utama dari terlaksananya suatu kegiatan. Pembangkit Listrik Tenaga Surya merupakan salah satu sumber energi terbarukan yang ramah lingkungan dan menjadi energi alternatif bagi masa depan.

Kegiatan praktikum yang dilakukan di laboratorium pada jenjang perkuliahan seperti di Politeknik Negeri Bandung (POLBAN) sangat bergantung dengan keberadaan sumber listrik. Kegiatan praktikum di laboratorium Teknik Konversi Energi POLBAN masih mengandalkan pasokan listrik yang berasal dari PLN. Laboratorium Surya Teknik Konversi Energi di POLBAN merupakan satusatunya laboratorium yang menggunakan sumber energi listrik dari Pembangkit Listrik Tenaga Surya Hibrida di setiap aktivitas perkuliahan.

Tulisan ini dimaksudkan untuk meninjau kecukupan pemakaian sumber energi dari sel surya untuk memenuhi beban di laboratorium Tenaga Surya/Lab Energi Terbarukan pada jurusan Teknik Konversi Energi POLBAN.

\section{PERANGKAT PLTS HIDBRIDA PADA LAB ENERGI TERBARUKAN}

Gambaran singkat untuk sistem PLTS Hibrida yang ada di Laboratorium Energi Terbarukan khususnya Lab Surya adalah seperti digambarkan di bawah ini.

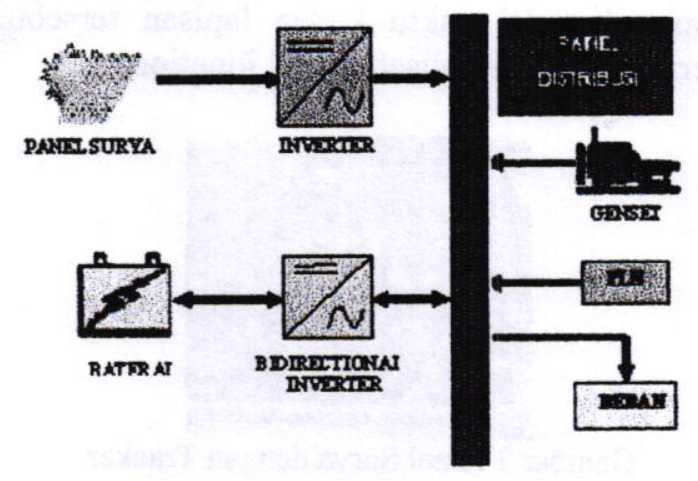

Gambar 1 Diagram PLTS Hibrida pada Lab Surya

Pada gambar di atas dapat dijelaskan bahwa, energi listrik yang didapat dari sinar matahari akan diubah oleh panel surya menjadi sumber listrik DC. Adapun beban adalah berupa perangkat yang menggunakan pasokan listrik AC. Sehingga pada system ini dibuat busbar AC sebagai busbar utama. 
PLTS Hibrida pada Lab Surya ini menggunakan inverter untuk mengubah tegangan DC yang berasal dari panel surya untuk menjadi tegangan AC. Dan juga menggunakan bidirectional inverter untuk menyimpan energy dari sel surya ke batere atau sebaliknya untuk menyalurkan energy dari batere ke beban. Pada system ini juga dilengkapi dengan genset dan akan aktif hanya jika suplai ini masih tetap tidak dapat mencukupi kebutuhan beban pada gendung Lab Surya. Tetapi pada kondisi khusus, suplay energy listrik dapat diambilkan dari PLN.

Beberapa panel utama yang terinstalasi sebagai sumber energy pada Lab Surya diantaranya adalah Panel Surya baik yang diberi tracker maupun Solar Array saja, Baterai, Genset, Inverter dan Bidierctional Inverter untuk 3 fasa, dan Busbar pada Panel Distribusi.

Penjelasan Singkat untuk perangkat utama PLTS pada Lab Surya adalah sebagai berikut.

\section{Panel Surya}

Panel surya terbuat dari sel surya polikristal, tahan digunakan dalam waktu yang lama. Daerah kelistrikan terbentuk dekat permukaan atas sel pada waktu kedua lapisan tersebut berinteraksi yang disebut $\mathrm{P}-\mathrm{N}$ junction.

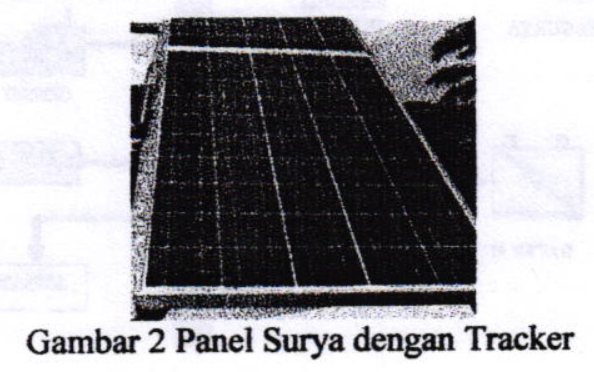

Ketika cahaya matahari mengenai permukaan sel surya maka daerah kelistrikan memberikan daya gerak dan secara langsung cahaya tersebut akan mendorong elektron-elektron dan menghasilkan arus listrik ketika sel surya dihubungkan dengan beban. Panel sel surya merupakan modul yang terdiri beberapa sel surya yang digabung dalam hubungkan seri dan paralel tergantung ukuran dan kapasitas yang diperlukan.
Sudut kemiringan panel surya disesuaikan dengan posisi lintang suatu daerah pada pemasangan panel surya, arah permukaan panel surya adalah ke utara untuk lokasi pada lintang selatan dan arah selatan untuk lokasi pada lintang utara.

Pemasangan panel surya tidak boleh terhalang oleh bayangan (pohon atau bangunan) pada permukaan panel surya, karena akan menurunkan atau membuat panel surya tidak akan menghasilkan keluaran daya.

\section{Solar Array}

Solar array merupakan serangkaian panel surya yang akan menangkap sinar matahari sebagai sumber energi. Pada siang hari solar array merubah tenaga surya menjadi listrik.

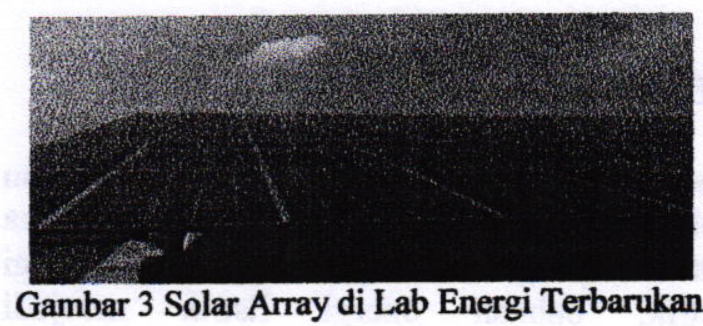

\section{Baterai}

Baterai adalah suatu alat yang digunakan untuk menyimpan energi. Energi yang disimpan dapat digunakan saat radiasi matahari rendah dan atau pada malam hari.

Deep cycle battery digunakan sebagai sistem penyimpanan pada PLTS di Lab Energi Terbarukan. Deep cycle battery dibuat untuk mampu dipakai energinya sebanyak $80 \%$ dari kapasitas pengisian tiap siklus. Baterai ini sangat cocok pada sistem hibrida apalagi jika baterai ini dirancang untuk persiklus tidak melebihi $50 \%$ kapasitasnya.

Ukuran baterai sangat tergantung pada, ukuran panel surya, dan komponen lainnya. Ukuran baterai yang terlalu besar baik untuk efisiensi operasi tetapi mengakibatkan kebutuhan investasi yang besar sebaliknya ukuran baterai kecil dapat mengakibatkan tidak tertampungnya daya dari sel surya. 


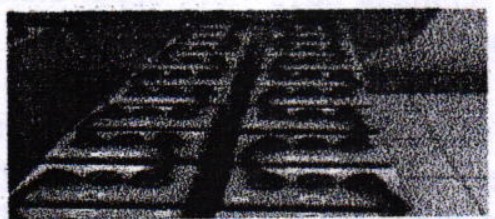

Gambar 4 Baterai Array

\section{Generator Set (GENSET)}

Generator set digunakan sebagai sumber energi komplementer agar beban selalu terpenuhi kebutuhannya akan listrik. Pada saat beban tinggi atau ketika listrik di dalam baterai minimum, generator diesel akan bekerja untuk menghasilkan listrik yang diperlukan. Untuk beban normal dan rendah, diesel tidak bekerja, tetapi untuk beban puncak atau energi yang tersimpan di baterai dibawah ambang batas, maka diesel akan mulai bekerja untuk mensuplai kekurangan beban, generator-set diharapkan dapat mensuplai tenaga listrik terutama untuk beban-beban prioritas.

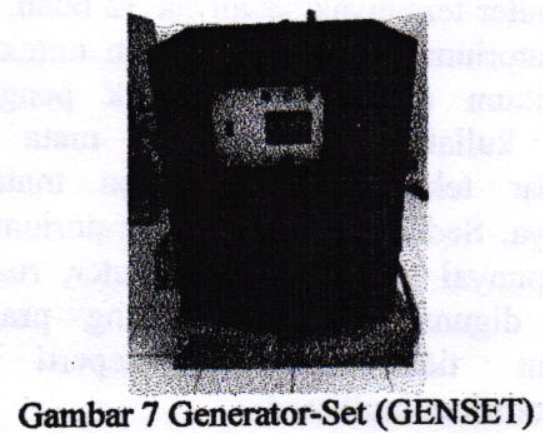

\section{Inverter}

Inverter ini digunakan untuk mengubah listrik DC yang berasal dari panel surya menjadi listrik AC untuk digunakan pada beban AC.

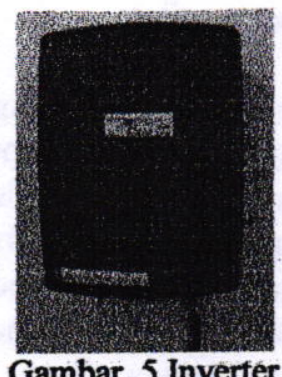

Pada sistem PLTS Hibrida di Lab Surya digunakan juga inverter bidirectional inverter mengkonversi listrik DC dari baterai menjadi listrik AC yang akan dicatu ke beban, dan juga sebagai charger untuk mengisi baterai dari busbar AC pada panel distribusi yang berasal dari inverter pada panel surya atau hasil daya dari genset maupun listrik dari PLN. Biderectional inverter juga berfungsi untuk mengatur proses termasuk mematikan dan menyalakan genset jika panel maupun baterai tidak mampu melayani beban.

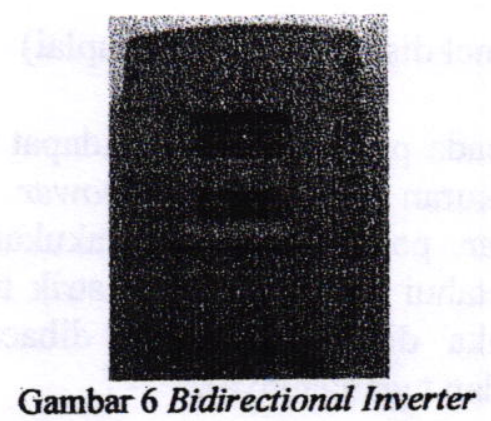

Selain sebagai bidirectional inverter, alat ini merupakan battery charge controller yang berfungsi untuk mengatur overcharging (kelebihan pengisian) jika baterai sudah penuh dan kelebihan voltase dari bus AC yang dapat mengurangi umur baterai. Beberapa fungsi lain dari battery charge controller yaitu mengatur arus untuk pengisian ke baterai, menghindari overcharging dan overvoltage, mengatur arus yang dibebaskan dan diambil dari baterai agar baterai tidak full discharge dan overloading, serta untuk memonitoring temperatur baterai.

\section{METODA PENGUKURAN}

Untuk mengetahui suplay daya optimal pada gedung Lab Energi Terbarukan yang berasal dari PLTS Hibrida dan pemakaiannya. Data yang diambil antara lain adalah berupa:

\section{Radiasi matahari}

Radiasi matahari akan didapat melalui pengukuran dengan alat piranometer, pengukuran ini dilakukan untuk mengetahui besarnya daya listrik yang dihasilkan oleh matahari $(\mathrm{W} / \mathrm{m})$.

\section{Inverter}

Data pada inverter akan didapat melalui pembacaan inverter dengan cara diketuk, dengan cara tersebut maka akan terbaca beberapa parameter yang dihasilkan oleh inverter. 


\section{Bidirectional inverter}

Data pada bidirectional inverter akan didapat melalui kartu MMC yang terdapat di dalam, dari SD card tersebut maka akan terbaca beberapa parameter sistem yang tersimpan di dalam inverter.

\section{Panel distribusi (power suplai)}

Data pada panel distribusi didapat melalui pengukuran dengan alat power quality analiser, pengukuran ini dilakukan untuk mengetahui besarnya daya listrik tiga fasa dan jika diperlukan dapat dibaca THD (arus dan tegangannya).

\section{Penggunaan beban gedung}

Besarnya penggunaan daya listrik serta konsumsi energi listrik pada gedung akan diketahui melalui jadwal perkuliahan.

\section{ANALISIS DAYA DARI PLTS HIBRIDA PADA LAB ENERGI TERBARUKAN}

\section{Suplay Daya}

Tabel 1 Komponen Sistem PLTS Hibrida

\begin{tabular}{|l|c|}
\hline \multicolumn{1}{|c|}{ Komponen Sistem } & Daya dan Energi \\
\hline Panel Surya & $18 \mathrm{~kW}$ \\
\hline Baterai & $60 \mathrm{kWh}$ \\
\hline Inverter & $18 \mathrm{~kW}$ \\
\hline Bidirectional Inverter & $15 \mathrm{~kW}$ \\
\hline Generator Set & $12,35 \mathrm{~kW}$ \\
\hline
\end{tabular}

Berdasarkan tabel di atas, sumber listrik yang dihasilkan dari panel surya yang berjumlah 102 panel dengan daya $18 \mathrm{~kW}$, besarnya radiasi yang dihasilkan setiap harinya beribahubah karena dipengaruhi oleh tinggi dan rendahnya radiasi matahari. Sumber listrik ini selanjutnya akan diubah oleh inverter menjadi sumber AC, berdasarkan spesifikasi alat yang ada didapat daya komponen ini sebesar $18 \mathrm{~kW}$. Seperti penjelasan sebelumnya, sumber listrik yang tidak langsung digunakan ke beban akan disimpan di dalam baterai, baterai sistem PLTS ini mempunyai 72 buah baterai dengan keseluruhan kapasitas $86,4 \mathrm{kWh}$ berjenis deep cycle. Baterai harus memiliki sisa sebesar $30 \%$ dari keseluruhan jumlah daya $(86,4$
kWh), sehingga daya yang dapat diambil dari penyimpanan adalah $60 \mathrm{kWh}$.

Daya yang tersimpan ini akan disalurkan melawati alat yang bernama bidirectional inverter, alat ini mempunyai kapasitas daya sebesar $15 \mathrm{~kW}$. Dari spesifikasi alat yang ada, daya panel keseluruhan adalah $18 \mathrm{~kW}$, inverter $18 \mathrm{~kW}$ juga namun pada bidirectional inverter hanya $15 \mathrm{~kW}$ maka pada malam hari PLTS tersebut dapat mensuplai energi listrik sebesar $15 \mathrm{KW}$ jika tanpa Genset.

\section{Beban Listrik}

Pada saat dilakukan pengukuran, gedung ini digunakan seperti penjelasan berikut. Gedung laboratorium surya ini mempunyai dua buah laboratorium yang digunakan untuk kegiatan praktikum, ruang ini adalah laboratorium multimedia dan laboratorium surya. Dari kedua ruangan ini, laboratorium multimedia adalah satu-satunya ruangan yang berisikan komputer terbanyak sebanyak 32 buah. Ruang laboratorium tersebut digunakan untuk ruang praktikum mata kuliah teknik pengaturan, mata kuliah sistem utilitas, mäta kuliah gambar teknik, dan beberapa matakuilah lainnya. Sedangkan ruang laboratorium surya mempunyai enam buah komputer, ruang ini juga digunakan sebagai ruang praktikum namun tidak sesering seperti ruang laboratorium multimedia.

Selain ruang laboratorium, gedung ini mempunyai ruang-ruang yang lain yang digunakan sebagai ruang dosen sebanyak sembilan buah ruang, satu buah ruang teknisi dan satu buah kelas, Ruang lainnya digunakan sebagai ruang rapat, ruang kalibrasi, ruang baca dosen, serta toilet.

Untuk sektor penerangan gedung, tidak semua ruang menggunakan lampu TL tetapi menggunakan lampu SL (toilet dan koridor). Dengan jenis lampu yang berbeda, maka daya dari setiap lampu pun berbeda. Berdasarkan spesifikasi alat dari sektor penerangan gedung, maka didapat bahwa daya yang terpasang untuk penerangan sebesar $5,52 \mathrm{~kW}$ sedangkan untuk sektor non penerangan dan HVAC daya yang terpasang adalah $\mathbf{8 , 9 4} \mathrm{kW}$. Sektor non penerangan serta HVAC terdiri dari komputer, dispenser, printer, dan AC. Sehingga daya 
yang terpasang dari semua beban yang ada di gedung sebesar $14,46 \mathrm{~kW}$.

Dengan pengukuran yang telah dilakukan yang terbagi menjadi dua jenis pengukuran, maka :

\section{Pengukuran beban gedung}

a. Pengukuran beban gedung maksimum

Pengukuran ini dilakukan dengan pemakaian beban non penerangan dan HVAC. Semua komputer yang berada di ruang multimedia, ruang lab surya, ruang teknisi, serta AC yang ada di ruang kalibrasi dihidupkan selama pengukuran dari pukul 08.00-15.00 WIB. Selain alat-alat di atas, lampu yang ada di dalam gedung pun ikut dinyalakan, tetapi pada saat pengukuran lampu yang ada di sembilan ruang dosen tidak nyalakan maka hanya menggunakan beban penerangan dari ruang kelas, teknisi, laboratorium surya dan multimedia, rapat, kalibrasi, ruang baca dosen, koridor ruang dosen, dan koridor lantai dua. Pemakaian seluruh beban ini mempunyai total daya sebesar 13,91 kW.

Dengan pemakaian beban seperti ini, jika dilihat dari segi daya sistem PLTS Hibrida supläi listrik yang diberikan olëh sistem masih memenuhi kebutuhan beban tersebut. Dari suplai daya sistem $15 \mathrm{~kW}$ tanpa genset harus menyala dan pemakaian beban $13,91 \mathrm{~kW}$ maka suplai sistem masih mempunyai sisa sebesar $1,09 \mathrm{~kW}$.

\section{b. Pengukuran beban setengah penuh}

Pengukuran dengan kondisi beban setengah maksimum dimana, sebagian komputer yang berada di ruang ruang multimedia, semua komputer di ruang lab surya, serta satu komputer di ruang teknisi dihidupkan serta penerangan gedung menyala pengukuran ini dilakukan dari pukul 08.00-15.00 WIB.

Selain alat-alat di atas, beban penerangan yang digunakan hanya dari ruang kelas, teknisi, laboratorium surya dan multimedia, rapat, kalibrasi, ruang baca dosen, koridor ruang dosen, dan koridor lantai dua. Pemakaian seluruh beban ini mempunyai total daya sebesar 9,96 kW.

Dengan pemakaian beban seperti ini, jika dilihat dari segi daya sistem PLTS Hibrida suplai listrik yang diberikan oleh sistem masih memenuhi kebutuhan beban tersebut. Dari suplai daya sistem $15 \mathrm{~kW}$ maka suplai sistem masih mempunyai sisa sebesar $5,04 \mathrm{~kW}$.

\section{Pengukuran selama lima hari kerja}

Pengukuran ini dilakukan dengan pemakaian beban disesuaikan dengan pemakaian beban gedung selama lima hari kerja, pengukuran dilakukan dari pukul 08.00-15.00 WIB. Berdasarkan jadwal perkuliahan yang didapat maka pemakaian daya yang terbesar pada hari senin dan terkecil di hari jum'at. Hari senin merupakan hari pemakaian daya listrik terbesar yaitu $13 \mathrm{~kW}$ dikarenakan pada hari ini penggunaan ruang multimedia selama enam jam perkuliahan, pada pukul 07.00-10.00 WIB ruang dipakai oleh kelas 1B untuk mata kuliah gambar teknik lalu dari pukul 10.00-13.30 WIB dipakai oleh kelas 3B untuk mata kuliah sistem utilitas. Selain penggunaan komputer di ruangan tersebut, dua buah komputer di ruang teknisi pun dinyalakan selama sembilan jam (pukul 07.00-16.00 WIB). Banyaknya penggunaan beban pada hari ini terlihat pada banyaknya pemakaian daya dari baterai untuk memenuhi kebutuhan beban tersebut.

Hari jum'at menjadi hari terendah sebesar $6,97 \mathrm{~kW}$ pemakaian daya listrik dikarenakan pada hari ini penggunaan ruang multimedia hanya dua jam 30 menit oleh kelas 1 TPTL dalam mata kuliah gambar teknik pada pukul 07.00-09.30 WIB. Komputer di ruang teknisi masih tetap menyala selama sembilan jam (pukul 07.00-16.00) disetiap harinya. Pemakaian listrik pada hari ini tidak banyak karena aktivitas yang dilakukan pun sedikit sehingga gedung laboratorium cenderung sepi dihari ini, gedung laboratorium sangat banyak digunakan pada hari senin dan kamis. Tabel pemakaian dapat diperlihatkan seperti tabel 2 berikut.

Tabel 2 Daya Listrik Gedung Lab Surya (berdasarkan Jadwal Kuliah)

\begin{tabular}{|l|c|}
\hline \multicolumn{1}{|c|}{ Hari } & $\begin{array}{c}\text { Pemakaian } \\
\text { Daya }(\mathrm{kW})\end{array}$ \\
\hline Senin & 13,00 \\
\hline Selasa & 6,97 \\
\hline Rabu & 6,64 \\
\hline Kamis & 8,22 \\
\hline Jum'at & 6,97 \\
\hline Rata-rata pemakaian daya & 8,42 \\
\hline
\end{tabular}


Dari tabel di atas, maka dapat diketahui bahwa rata-rata pemakaian beban pada gedung laboratorium adalah $8,42 \mathrm{~kW}$ selama lima hari aktivitas perkuliahan.

\section{ANALISIS KONSUMSI ENERGI LISTRIK}

Berdasarkan analisis daya sebelumnya, dikarenakan hari senin adalah pemakaian daya terbesar maka konsumsi energi hari ini pun besar pula yaitu $41,32 \mathrm{kWh}$ sedangkan untuk hari jum'at konsumsi energi adalah 20,21 $\mathrm{kWh}$. Konsumsi energi rata-rata gedung dari kelima hari perkuliahan sebesar 29,05 kWh.

Tabel 3 Konsumsi Energi Listrik Gedung Lab Surya (berdasarkan Jadwal Kuliah)

\begin{tabular}{|l|c|}
\hline \multicolumn{1}{|c|}{ Hari } & $\begin{array}{c}\text { Konsumsi } \\
\text { Energi (kWh) }\end{array}$ \\
\hline Senin1 & 41,32 \\
\hline Selasa2 & 29,27 \\
\hline Rabu3 & 20,22 \\
\hline Kamis4 & 34,25 \\
\hline Jum'at5 & 20,21 \\
\hline $\begin{array}{l}\text { Total Konsumsi Energi dalam } \\
\text { lima hari kerja }\end{array}$ & 145,27 \\
\hline Rata-rata Konsumsi Energi & 29,05 \\
\hline
\end{tabular}

Dari jadwal perkuliahan maka dengan memadatkan waktu perkuliahan di gedung laboratorium surya beserta pemakaian beban, didapat bahwa dari sembilan jam perkuliahan (07.00-16.00) setiap harinya pemakaian listrik ini tidak penuh digunakan. Pemakaian energi listrik yang optimal disetiap harinya yaitu hari senin pemakaian energi listrik rata-rata dari pukul 10.00-13.40 WIB (tiga jam 40 menit), dihari selasa pemakaian energi dari pukul 07.00-11.00 WIB (empat jam), untuk hari rabu pukul 11.30-14.00 WIB (dua jam 30 menit), di hari kamis pada pukul 07.00-11.00 WIB (empat jam), dan dihari jum'at saat pukul 07.00-09.30 WIB (dua jam 30 menit) sehingga keseluruhan pemakaian beban optimal selama lima hari kerja adalah 15 jam 50 menit. Jika dirata-ratakan pemakaian energi listrik selama lima hari kerja adalah dari selama tiga jam delapan menit.

\section{Perencanaan Penambahan Beban Pada Gedung Lab Surya}

Perencanaan penambahan beban hanya pada sektor non penerangan saja itu dikarenakan sektor penerangan tidak dapat lagi untuk ditambah. Penambahan yang dilakukan adalah dengan penggunaan laptop (dengan daya setiap laptop 60 Watt) pada setiap ruang dosen yang berjumlah sembilan ruangan. Penambahan beban yang akan dilakukan daya terpasang sektor non penerangan dan HVAC menjadi $9,48 \mathrm{~kW}$ yang semula hanya $8,94 \mathrm{~kW}$ dengan presentase penambahan beban adalah $6,04 \%$.

Dengan kapasitas sistem sebesar $15 \mathrm{~kW}$ dan adanya penambahan beban maka daya yang terpasang untuk sektor non penerangan dan HVAC pada gedung menjadi $9,48 \mathrm{~kW}$. Maka daya yang terpasang kini yang semula 14,46 $\mathrm{kW}$ menjadi $15 \mathrm{~kW}$. Dengan daya yang terpasang pada saat ini menunjukkan bahwa beban pada gedung telah maksimum dan tidak dapat ditambah lagi. Selain penambahan beban pada laptop, gedung laboratorium tidak dapat menambahkan beban dengan kapasitas daya melebihi daya laptop yang direncanakan.

\section{KESIMPULAN}

- Gedung Laboratorium Surya ini mempunyai tiga sektor beban yaitu sektor penerangan, non penerangan, serta HVAC. Jumlah daya terpasang dari sektor penerangan adalah $5,52 \mathrm{~kW}$ dan dari sektor non penerangan maupun HVAC sebesar $8,94 \mathrm{~kW}$. Seluruh beban ini disuplai dari sel surya dengan kapasitas $18 \mathrm{kWp}$ melalui inverter dipakai melayani beban tersebut, dan atau melalui alat bidirectional inverter dengan kapasitas komponen yaitu $15 \mathrm{~kW}$ disimpan ke batere dan jika pasokan dari sel surya kurang dalam melayani beban maka dapat diambilkan dari batere ini melalui bidirectional inverter tersebut.

- Pemakaian daya listrik terbesar dari lima hari aktivitas perkuliahan adalah $13 \mathrm{~kW}$ di hari senin dimana hari tersebut beban paling banyak digunakan. Untuk pemakaian daya listrik terkecil sebesar 6,97 kW pada hari jum'at karena dihari ini kegiatan perkuliahan sangat sedikit dilakukan sehingga pemakaian listrik pun tidak banyak.

- Berdasarkan jadwal perkúliahan semester genap Teknik Konversi Energi didapat bahwa konsumsi energi gedung 
Laboratorium Surya tertinggi berada di hari senin sebesar $41,32 \mathrm{kWh}$ sedangkan konsumsi energi terendah di hari jum'at sebesar 20,21 kWh.

\section{DAFTAR PUSTAKA}

Krarti, Moncef. 2000. Energy Audit of Buliding System. London: CRC Press

Jackson, Frank. 2008. Planning and Installing Photovoltaic Systems Second Edition. London: Earthscan.

Kadir, Abdul. 1982. Energi. Jakarta : UI Press.

PT Azet Surya Lestari. Pembangkit Listrik Tenaga Surya Skala Menengah-Besar (Hybrid, Grid- Interractive). Tanggerang : Ruko Sentra Menteng.

Samuel L. Abreu9, Sergio Colle, Karime L. Z. Glitz, Ricardo Rüther and Hans Georg Beyer. 2000. Isolated Hybrid PV-Diesel Power Plants Design Method. RIO 3 World Climate \& Energy Event. Brazil : University of Santa Catarina Lab SolarDepartment of Mechanical Engineering.

SMA Solar Technology AG.2009. PV Inverter Sunny Minny Central 4600/5000A/6000A Installation Guide. Jerman : Sonnenallee.

SMA Solar Technology AG .2009. Sunny Island 5048 Installation and Instruction Manual. Jerman: Sonnenallee. 